\title{
The effects of oak (Quercus) restoration on forest trajectory and small mammal use in the southern Cumberland Plateau, USA
}

\author{
C. Ken Smith ${ }^{1 *}$, Amy J. Turner ${ }^{2}$, J. Kevin Hiers ${ }^{3}$, Julie Garai ${ }^{4}$, W. Nate Wilson ${ }^{2}$ and A. Nicole Nunley ${ }^{1}$
}

\begin{abstract}
Background: Thinning and prescribed fire are increasingly used to promote oak (Quercus L. spp.) regeneration in forest restoration projects across the eastern United States. In addition to monitoring the response of vegetation to these reductions in basal area, the research and land management community has become focused on the response of wildlife to these treatments. In a landscape in which forest ownership is fragmented and dominated by non-industrial private landowners, predicting the range of wildlife and vegetation response to treatments will be necessary to facilitate adoption of a landscape-scale approach to oak restoration. The goal of this study was to examine the efficacy of restoring privately owned, mixed forest stands that were partially planted in loblolly pine (Pinus taeda L.) and eastern white pine (Pinus strobus L.) to oak-dominated communities through the use of thinning and prescribed fire. Additionally, the study documented implications of these treatments on small mammal activity in the southern Cumberland Plateau.

Results: Following basal area reductions ranging from 30 to $60 \%$ and three prescribed fires across three sites, mean oak seedling densities rose from $10200 \mathrm{ha}^{-1}$ to $17900 \mathrm{ha}^{-1}$. Post-treatment oak seedling densities were related to pretreatment densities $\left(R^{2}=0.55, P<0.0001\right)$ and the number of oak trees $>20 \mathrm{~cm}$ diameter within $10 \mathrm{~m}$ of plot center $\left(R^{2}=0.15, P=0.01\right)$. Three years after the last prescribed fire, bat activity (mean passes per night) was significantly higher in the treated stands compared to adjacent undisturbed forest. We did not detect any significant differences in rodent activity between our treated stands and forest controls for two of the three years studied.

Conclusions: The results of this study highlighted the within-stand variation that drives post-harvest vegetation trajectories. Three years after the last prescribed fire, bats exhibited higher foraging activity in the treated sites that had lower basal area and very little midstory clutter. Our three-year summer monitoring of rodent activity following the last of the three prescribed fires revealed differences in rodent activity between our treated sites and adjacent forest controls only during $2018(P=0.001)$. These results will assist private landowners in the region as they consider the costs and benefits of oak forest restoration.
\end{abstract}

Keywords: bats, mechanical thinning, oak restoration, prescribed fire, rodents

\footnotetext{
* Correspondence: ksmith@sewanee.edu

${ }^{1}$ Department of Earth and Environmental Systems, The University of the

South, 735 University Avenue, Sewanee, Tennessee 37383, USA

Full list of author information is available at the end of the article
}

\section{Springer Open}

(c) The Author(s). 2020 Open Access This article is licensed under a Creative Commons Attribution 4.0 International License, which permits use, sharing, adaptation, distribution and reproduction in any medium or format, as long as you give appropriate credit to the original author(s) and the source, provide a link to the Creative Commons licence, and indicate if changes were made. The images or other third party material in this article are included in the article's Creative Commons licence, unless indicated otherwise in a credit line to the material. If material is not included in the article's Creative Commons licence and your intended use is not permitted by statutory regulation or exceeds the permitted use, you will need to obtain permission directly from the copyright holder. To view a copy of this licence, visit http://creativecommons.org/licenses/by/4.0/. 


\section{Resumen}

Antecedentes: Los raleos y las quemas prescriptas están siendo usados de manera creciente para promover la regeneración del roble (Quercus L. spp.) en proyectos de restauración a través del este de los EEUU. Sumado al monitoreo de la respuesta de la vegetación a esas reducciones en el área basal, la comunidad de investigadores y manejadores de tierras se ha enfocado en la respuesta de la fauna silvestre a esos tratamientos. En un paisaje en el cual la tenencia del bosque está fragmentada y dominada por propietarios privados no industriales, el predecir el rango de las respuestas de la fauna silvestre y de la vegetación a estos tratamientos va a ser necesario para facilitar la adopción de una aproximación a nivel de paisaje para restaurar los bosques de robles. El objetivo de este estudio fue examinar la eficacia de la restauración de stands en bosques privados mixtos que fueron parcialmente plantados con pino taeda (Pinus taeda L.) y con pino blanco del este (Pinus strobus L.), a comunidades de bosques de roble a través del uso de los raleos y las quemas prescriptas. Adicionalmente, el estudio documentó las implicancias de esos tratamientos en la actividad de pequeños mamíferos en la Meseta de Cumberland del sur.

Resultados: Después de reducciones de área basal que oscilaron del 30 al 60\% y tres quemas prescriptas a través de los sitios, la densidad media de plantines aumentó de $10.200 \mathrm{ha}^{-1}$ a $17.900 \mathrm{ha}^{-1}$. Las densidades de plantines fueron relacionadas con las densidades pre tratamientos $\left(R^{2}=0.55, P<0.0001\right)$ y el número de árboles de robles $>20 \mathrm{~cm}$ de diámetro dentro de $10 \mathrm{~m}$ del centro de las parcelas $\left(R^{2}=0.15, P=0.01\right)$. Tres años después de la última quema prescripta, la actividad de los murciélagos (pasajes medio por noche) fue significativamente mayor en los rodales tratados comparados con el bosque no disturbado adyacente. No detectamos diferencias significativas en la actividad de roedores entre los rodales tratados y los controles para dos de los tres años estudiados.

Conclusiones: Los resultados de este estudio resaltan la variación intra-rodal que determinan las trayectorias de la vegetación post cosecha. Tres años después de la última quema prescripta, los murciélagos exhibieron una más alta actividad forrajeadora en los sitios tratados que tenían bajas áreas basales y muy poca complejidad espacial en el estrato medio del bosque. Nuestros tres años de monitoreo de verano sobre la actividad de los roedores seguido de la última de las tres quemas prescriptas revelaron diferencias en la actividad de los roedores entre nuestros sitios tratados y el bosque adyacente usado como control solo durante $2018(P=0.001)$. Estos resultados asistirán a los productores privados a considerar los costos y beneficios de la restauración de los bosques de roble.

\section{Background}

The ongoing and widespread conversion of oak (Quercus spp.)-dominated forests in the eastern United States to forests dominated by shade-tolerant tree species is well documented (Abrams 1992; Nowacki and Abrams 2008; Reid et al. 2008). The elimination of fire as a disturbance factor (Brose et al. 2001), the increased densities of shade-tolerant tree species in the midstory and understory (Nowacki and Abrams 2008), the decreased flammability of non-oak litter layers (Kreye et al. 2018), and a lack of oak recruitment into the sapling stage (Arthur et al. 2012) are some of the major factors contributing to changes in these oak-dominated systems. In response, the research and management communities across the eastern US landscape have conducted a large number of experiments designed to better understand how prescribed fire or its interaction with silvicultural manipulations affect oak seedling recruitment and sapling development (Brose et al. 2012).

Several long-term projects examining the effects of fire on oak in the understory and midstory have taken place on the Allegheny and Cumberland plateaus, where the Allegheny-Cumberland dry oak forests and woodlands are widespread (https://www.natureserve.org/). Research in those environments has indicated that prescribed fire alone has mixed results in promoting oak regeneration (Arthur et al. 1998; Hutchinson et al. 2005; Green et al. 2010) or altering midstory composition to favor oak survival (Blankenship and Arthur 2006; Hutchinson et al. 2012). On the Cumberland Plateau, Keyser et al. (2017) remarked that shorter fire return intervals (two burns over seven years) were beneficial to oak-hickory recruitment but that non-oak competition remained high in the absence of other silvicultural manipulations. On the Allegheny Plateau, research combining two prescribed fires with 10 to $20 \%$ midstory basal area reductions resulted in improved oak and hickory regeneration on xeric sites (Iverson et al. 2008). In the same region, Albrecht and McCarthy (2006) reported declines in oak recruitment four years after thinning (20 to $30 \%$ basal area reductions) plus prescribed fire. This study emphasized the need for additional fires to help control sassafras (Sassafras albidum [Nutt.] Nees) and yellow-poplar (Liriodendron tulipifera L.) seedling recruitment, as well as red maple (Acer rubrum L.) sprouting. In the northern Cumberland Plateau, Parrott et al. (2012) reduced total basal area by $20 \%$ via midstory removals and found that survival and growth of white oak (Quercus alba L.) 
and black oak (Quercus velutina Lam.) seedlings improved after treatment, but red maple and other shadetolerant species outcompeted oak saplings seven years following treatments in the absence of fire.

As the extensive work examining the response of eastern hardwood forests to prescribed fire and mechanical thinning has progressed, land managers have been increasingly interested in the response of wildlife to these treatments (Harper et al. 2016). In the southeastern US and elsewhere, research in treated forests has demonstrated positive, negative, and neutral effects on breeding birds (Artman et al. 2001), lepidopteran communities (Waltz and Covington 2004; Summerville and Lewis 2005), and amphibians and reptiles (Greenberg and Waldrop 2008). In recent years, the effects of forest management on bat habitat, bat foraging activity, and non-volant mammal populations has gained attention due to the increased use of prescribed fire (Ford et al. 1999; Silvis et al. 2016).

There are 16 species of bats that live in Tennessee and, during the growing season, all of these species have maternity and bachelor colonies that utilize an array of microhabitats including forest canopies and their foliage, cavities in live and dead trees, and trees with sloughing bark (Campbell 2017). Several studies indicated that forest riparian areas had higher bat activity compared to other forest environments and that high tree densities and midstory clutter reduce foraging activity for some bat species (Owen et al. 2004; Menzel et al. 2005; Loeb and Waldrop 2008). On the Cumberland Plateau in Tennessee, USA, Cox et al. (2016) reported that stands that were thinned and burned supported higher bat activity for larger-bodied bats such as the eastern red bat (Lasiurus borealis Muller), the evening bat (Nycticeius humeralis Rafinesque), and the big brown bat (Eptesicus fuscus Beauvois). On the Allegheny Plateau in southern Ohio, USA, forest management practices that reduced structural volume in the understory and mid-canopy increased suitable habitat for foraging bats (Titchenell et al. 2011).

For non-volant mammals, Keyser and Ford (2006) noted that prescribed fire had little to no effect on small mammal populations in eastern US oak-hickory forests. In southern Appalachian forests in western North Carolina, USA, Ford et al. (1999) examined small mammal populations before and after a high-intensity prescribed fire, and they did not detect significant changes for most of these mammals after the fire. Ford et al. (1999) indicated that many small mammals move under the forest litter and utilize tunnels, root holes, and spaces under coarse woody debris, and that these spaces provided protection during fires.

Currently, prescribed burning in the oak-dominated forests of the eastern US occurs primarily on public lands, and Arthur et al. (2012) emphasized the importance of including private lands in these efforts to maintain oak-dominated forests. In the southeastern US, non-industrial private landowners represent $>60 \%$ of the total forest ownership in the region (Oswalt and Smith 2014); thus, private landowner participation is critical in landscape-scale management of prescribed fire and silvicultural treatments that sustain oak-hickory forests. For many private landowners, legal and financial hurdles related to prescribed fire liability, market disincentives for hardwood timber with fire scars, and the financial costs associated with equipment and personnel needed to safely apply prescribed fire limit the use of these treatments (Haines et al. 2001). In addition, since attempts to promote oak restoration with thinning and fire have met with inconsistent results, the difficulties in establishing predictable restoration trajectories may ultimately limit treatment area on private lands.

In the Cumberland Plateau of Tennessee, private landowners have diverse interests that include maintaining their oak-dominated forests for commercial benefit, water quality, wildlife habitat, and aesthetics (Tian et al. 2015). In this region, many landowners converted upland oak-dominated forests to loblolly pine (Pinus taeda L.) plantations from the 1960s to 2000s when there was an active market for both pine pulpwood and sawlogs (McGrath et al. 2004). Local markets for pine have since declined, and a cohort of retired landowners have moved into the region and are typically less dependent on their land for income and greatly value scenic resources (Poudyal et al. 2014). As expectations for commercial timber harvesting decline and objectives related to wildlife habitat and aesthetics increase, forest restoration may become increasingly important for these private landowners in future years.

The primary goal of this study was to document restoration trajectories for privately owned and nonindustrial forest stands on the southern Cumberland Plateau that were partially planted in loblolly pine and eastern white pine (Pinus strobus L.) in the 1960s. Published guidelines and recommendations were used to determine thinning intensities and fire frequencies (e.g., Brose and Van Lear 1998; Brose et al. 2006; Iverson et al. 2008). Our specific objectives were to: (1) examine the effectiveness of our treatments in the recovery of native hardwood communities, particularly with regard to our primary upland oak species including white oak, black oak, chestnut oak (Quercus montana Willd.), and scarlet oak (Quercus coccinea Muenchh.); and (2) examine small mammal use of treated stands and untreated forest controls three years after the last of our prescribed fires to better understand animal responses to our restoration efforts. 


\section{Methods}

\section{Site description}

Three experimental forest sites were used in this study, all located on the property of The University of the South in Sewanee, Tennessee, USA, on the southern Cumberland Plateau physiographic province (latitude: $35.201^{\circ}$, longitude: $-85.912^{\circ}$; Fig. 1 ). These very similar experimental sites were on the top of the plateau with slopes ranging from 0 to $4 \%$, at elevations of approximately $600 \mathrm{~m}$. Site 1 was located in the northwest section of the university property, Site 2 was located on the northern section, and Site 3 was located to the south (Fig. 1). The sites ranged in size from 10 to $12 \mathrm{ha}$, and all experimental forest stands were growing on highly weathered and well-drained Ultisols (sandy loams) with depths from 0.5 to $1.5 \mathrm{~m}$. Average rainfall in this region ranges from 1400 to $1500 \mathrm{~mm}$ per year. Prior to 1955 , all three sites were harvested at least once and were likely burned several times for livestock forage. In the mid 1960s, each site was partially cleared and planted in pine (mostly loblolly and eastern white). At the time of treatment, approximately one third of each site was occupied by planted pine at varied densities. Eastern white pine was also planted along the edges of fire lanes (along the stand edges) in the late 1960s and early 1970s. Sites 2 and 3 had substantial numbers of eastern white pine saplings in the understory prior to our treatments.
Prior to the thinnings at each site, overstory cover was dominated by white oak, chestnut oak, black oak, scarlet oak, yellow-poplar, and loblolly pine. The midstory at each site consisted primarily of black gum (Nyssa sylvatica Marsh.), sassafras, sourwood (Oxydendrum arboretum [L.] DC), red maple, and oak. Groundcover at each site was dominated by tree seedlings (primarily hardwoods), low bush blueberry (Vaccinium pallidum Ait.), and greenbriar (Smilax bona-nox L. and Smilax rotundifolia L.).

\section{Treatments}

Site 1 was thinned in winter 2009-2010 with a hydro-ax feller buncher and grapple skidder. Before the harvest, we marked all of the trees to be left in the stand and removed all hardwoods less than $30 \mathrm{~cm}$ diameter at breast height (dbh; $1.37 \mathrm{~m}$ above ground) and $100 \%$ of the pine. After the harvests, all treated forests resembled a shelterwood with patch openings of 0.5 to 0.75 ha where the pre-treatment pine density was greatest. In addition, our harvesting treatment eliminated the midstory at all three sites. The prescribed fires at all the experimental sites were conducted two to four days after a rain event, with winds ranging from 3 to $12 \mathrm{~km} \mathrm{hr}^{-1}$, temperatures from 18 to $26{ }^{\circ} \mathrm{C}$, and relative humidities between 30 and $45 \%$. All fire behavior was documented with multiple observations of flame lengths recorded by a field observer,

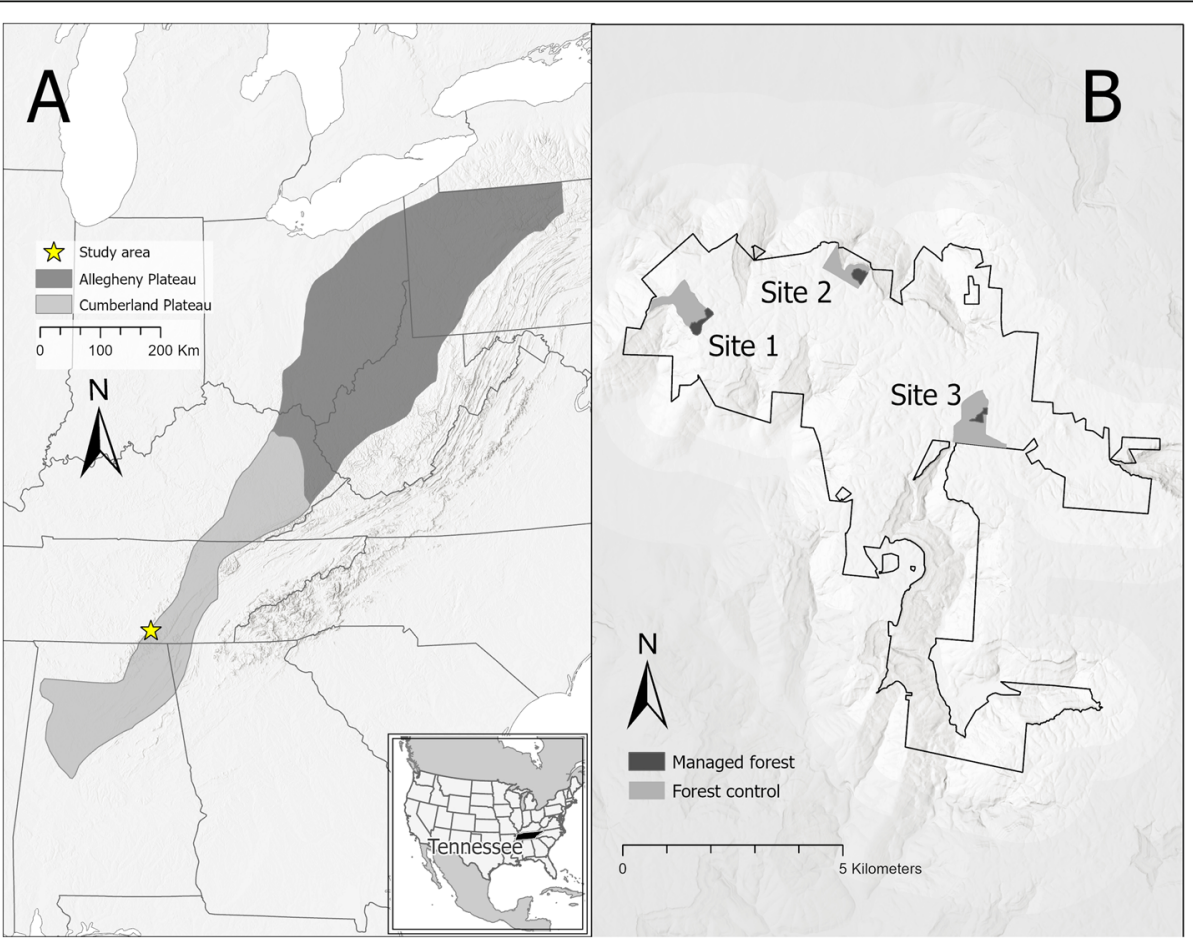

Fig. 1 (A) The Allegheny and Cumberland Plateaus in the eastern United States and the location of the study site in southern Tennessee and (B) a map of The University of the South's property boundary (5263 ha) with the location of the three forested sites used to examine the effects of oak (Quercus) restoration on forest trajectory and small mammal use in the southern Cumberland Plateau (2009 to 2018) 
and on-site weather was recorded hourly using a Kestral 3000 unit (KestralMeters.com, Boothwyn, Pennsylvania, USA) during burn observations. Post-burn coverage across each unit was estimated by a systematic walkthrough within one day of each burn.

At Site 1, 34 metric tons ha ${ }^{-1}$ of hardwood pulpwood, 47 metric tons of pine pulpwood $\mathrm{ha}^{-1}$, and 9 metric tons of pine sawlogs $\mathrm{ha}^{-1}$ were removed. Tree tops were pulled from the primary landing and scattered throughout the site prior to our use of prescribed fire. The first prescribed fire at this site took place in May 2010 (two months post thinning), was of low intensity (flame lengths $\sim 1 \mathrm{~m}$ ), and the burn covered $75 \%$ of the site. A second fire was applied to Site 1 in April 2013 (three years post thinning) and fire intensity ranged from low (0 to $1 \mathrm{~m}$ flame lengths) to moderate (1 to $3 \mathrm{~m}$ flame lengths) with more thorough coverage of the site ( $99 \%)$. Higher fire intensity was observed through consumption of loblolly pine regeneration, which had grown to heights $>1 \mathrm{~m}$ in some locations. The third fire at this site was applied in April 2016 (six years post thinning) and was of low intensity, covering $85 \%$ of the site.

Site 2 was thinned during the winter of 2011 and into the spring of 2012 with a forwarder and a processor (a mechanized tree harvester capable of producing material cut to length, and stacking the logs). As with Site 1, all the residual trees were marked before harvest, and we removed all hardwoods less than $30 \mathrm{~cm}$ dbh as well as all the loblolly and eastern white pine. At this site, 30 metric tons of hardwood pulpwood ha ${ }^{-1}, 56$ metric tons of pine pulpwood $\mathrm{ha}^{-1}$, and 7 metric tons of pine saw$\operatorname{logs} \mathrm{ha}^{-1}$ were removed. A small group of shortleaf pine (Pinus echinata P. Mill.) and Virginia pine (Pinus virginiana P. Mill.) were retained on the site (basal area of $\left.3.2 \mathrm{~m}^{2} \mathrm{ha}^{-1}\right)$. Compared to the feller buncher and grapple skidders used on Sites 1 and 3, this logging technology resulted in a more even distribution of 10- and 100-hour fuels across the site. The first prescribed fire at this site took place in March 2013 (one year after thinning), was of low to moderate intensity, and covered $80 \%$ of the site. We observed maximum flame lengths up to 1 to $3 \mathrm{~m}$ in height where cured pine slash was the most abundant. The second fire was applied in March 2014 (two years after thinning), was of low intensity, and covered approximately $85 \%$ of the site. The third fire was applied in April 2016 (four years post thinning), was of low intensity, and covered $85 \%$ of the site.

Site 3 was thinned during the summer of 2013 with a hydro-ax and a grapple skidder. As with Sites 1 and 2, hardwood trees $<30 \mathrm{~cm}$ dbh were removed, as was most of the pine component (loblolly and eastern white pine). At this site, 40 metric tons $\mathrm{ha}^{-1}$ of hardwood pulpwood and 35 metric tons $\mathrm{ha}^{-1}$ of pine pulpwood were removed. A small number of mature loblolly and shortleaf pine were retained in this stand (basal area of $4.7 \mathrm{~m}^{2} \mathrm{ha}^{-1}$ ). Tree tops were removed from the primary landing and distributed throughout the site. The first prescribed fire in this site took place in March 2014 (nine months post thinning), was of low intensity ( 0.5 to $1 \mathrm{~m}$ flame lengths), and covered $75 \%$ of the site. The second prescribed fire occurred in March 2015 (two years post thinning), with similar fire behavior, and covered $80 \%$ of the site. The third treatment burn was applied in April 2016 (three years post thinning), and was characterized by low-intensity fire behavior, covering $85 \%$ of the site.

\section{Pre- and post-treatment data collection}

Prior to our treatments, permanent plots were established at each of the three sites, including 17 plots at Site 1,10 plots at Site 2, and 14 plots at Site 3. The plots were chosen based on a grid that evenly distributed the sampling points across each site. At each sampling point, we initially conducted a 0.1 ha fixed radius inventory of all trees $>4 \mathrm{~cm}$ dbh to estimate basal area $\left(\mathrm{m}^{2} \mathrm{ha}^{-1}\right)$. We also conducted a nested 0.001 ha inventory of all seedlings $(<1.37 \mathrm{~m}$ height $)$ at each sampling point. In addition, we estimated the percent cover of tree seedlings, graminoids, Smilax spp. (Smilax bona-nox L. and Smilax rotundifolia L.), Vaccinium spp. (primarily Vaccinium pallidum Ait.) and blackberry (Rubus allegheniensis Porte) inside each 0.001 ha subplot during each sampling period. Seedling inventories and plant cover estimates were conducted in late summer following each burn on all sites. The final seedling count, cover estimates, and basal area measurements occurred two years after the last burn at each site. We also estimated the numbers of saplings (by species) at each oak restoration site in our inventory that took place two years after the last of the prescribed fires. Saplings were trees $>1.3 \mathrm{~m}$ in height and $<2 \mathrm{~cm}$ in diameter. The final post-treatment estimate of basal area was obtained using a variable radius plot centered on each permanent plot.

Post-treatment litter depth (O horizon) was estimated at each site in August 2016, after the last prescribed fires were completed. We took these measurements to assess whether our treatments created different litter depths among our three sites, which could have affected seedling recruitment via acorns and other mast. Forest floor and litter depth were collected at each permanent 0.001 ha subplot by compositing four measurements in cardinal directions (north, south, east, and west) at the edge of each subplot. These four litter depths were then averaged to estimate a subplot mean. In addition, each time we visited the 0.001 ha seedling plots, we also noted which plant species showed evidence of deer browse. We did not quantify the number of plants browsed, only noting which species were affected per plot. 


\section{Mammal monitoring}

To assess how our cumulative treatments affected rodent communities, 48 traps were deployed at each of the three experimental sites, and 48 traps were also placed at three adjacent unmanaged forest controls after we had completed our last prescribed fires. Using a predetermined azimuth bearing, sampling grids were typically arranged in either a $40 \mathrm{~m} \times 120 \mathrm{~m}$ or $20 \mathrm{~m} \times$ $240 \mathrm{~m}$ pattern dependent upon topography. Large Sherman $0.63 \mathrm{~cm}$ aluminum folding traps $(7.6 \mathrm{~cm} \times$ $8.5 \mathrm{~cm} \times 2.9 \mathrm{~cm}$; H.B. Sherman Traps, Inc., Tallahassee, Florida, USA) were baited with sunflower seeds and Sevin 5\% dust (GardenTech, Palatine, Illinois, USA) was applied beneath traps in order to deter insects (Kraig et al. 2010; Duffie et al. 2019). In June of 2017, 2018, and 2019, traps were set on Monday mornings and checked each subsequent morning to prevent mortality of captured mammals from heat exposure. Traps were checked for four consecutive days and removed on Fridays of the same week. Captured mammals were identified to species and sexed, and hind foot length, tail length, and body length were measured to the nearest millimeter. All captures were released at the capture location. Starting in 2018, when captured, mammals were marked with a blue or black indelible marker in order to account for recapture rates (Wolcott et al. 2014). We followed suggested guidelines for the use of wild animals in research as suggested by the Institute of Animal Care and Use Committee of the University of the South and the American Society of Mammalogists (Sikes and Gannon 2011).

In summer 2019 (mid June to mid August), we conducted bat echolocation call monitoring for five weeks in the three treated sites and three unmanaged forest sites using Wildlife Acoustics SM4BAT (Wildlife Acoustics, Concord, Massachusetts, USA) zero cross acoustic detection technology to passively detect, record, and store bat echolocation call sequences (Cox et al. 2016; Austin et al. 2018). During this time period, we sampled 34 trap nights in the treated forest and 42 trap nights in the unmanaged control forest. Prior to deployment, we calibrated all units using an ultrasonic calibrator (Wildlife Acoustics 2020). Basal areas in the unmanaged forest ranged from 23 to $28 \mathrm{~m}^{2} \mathrm{ha}^{-1}$, and these forests had a dense midstory of sassafras, black gum, sourwood, red maple, oak, and a variety of hickory (Carya Nutt.) species. We also noted that there was a small reservoir within one kilometer of all of our sampling sites (for bat access to water).

At each experimental site, we secured the monitors to a tree, approximately $1 \mathrm{~m}$ above the ground, secured with locks attached to 12-volt batteries housed in large utility boxes. The external microphones were secured to poles approximately $3 \mathrm{~m}$ above the ground to ensure optimal detection of bat calls (Parkins and Clark 2015; Cox et al. 2016). Data were stored on 64GB memory cards and then uploaded to an external hard drive, where they were processed. The acoustic monitoring equipment used microphones to detect and record bat echolocation searching calls. The acoustic monitors were programmed to begin recording calls starting 30 minutes before sunset and ended 30 minutes after sunrise each night (Cox et al. 2016). Each night that the acoustic detecting equipment was deployed was termed a trap night. The acoustic detectors recorded each echolocation pass as bats flew near the monitors and emitted their calls. We identified calls using Kaleidoscope Pro 4.5.4 (Wildlife Acoustics, Inc., Maynard, Massachusetts, USA), using the default signal parameters in Kaleidoscope (8 to $120 \mathrm{KHz}$ frequency range, 500 maximum inter-syllable gap, two minimum number of pulses, enhanced with advance signal processing) and filtered for the 12 species found in our study area. Each data file consisted of a recorded bat call, and we note that the total number of bats calls may not correlate with overall bat abundance (Bernard and McCracken 2017). NOISE and NO ID files consisted of files that were less than two pulses, short duration, or low-frequency noise that could be attributed to wind, insect noise, or rain (Bernard and McCracken 2017). After processing, we manually reviewed the acoustic files for species determination and removed the misidentified files. We did not estimate percent certainty scores. To minimize error, species with similar call characteristics were combined (Yates and Muzika 2006; Titchenell et al. 2011; Cox et al. 2016). The species groups were: LABO/NYHU (eastern red bat, Lasiurus borealis Muller; and evening bat, Nycticeius humeralis Rafinesque), EPFU/LANO (big brown bat, Eptesicus fuscus Beauvois; and silver-haired bat, Lasionycteris noctivagans LeConte), LACI (hoary bat, Lasiurus cinereus Beauvois), PESU (tri-colored bat, Perimyotis subflavus F. Cuvier), CORA (Rafinesque's big-eared bat, Corynorhinus rafinesquii Lesson), and MYOTIS (Myotis spp.). The MYOTIS category included five species: southeastern bat (Myotis austroriparius Rhoads), gray bat (Myotis grisescens A. H. Howell), northern long-eared bat (Myotis septentrionalis Trouessart), Indiana bat (Myotis sodalis Miller and G. M. Allen), and the little brown bat (Myotis lucifugus Le Conte). Calls that were recorded but were too short in duration to be identified were classified as NO ID and sounds that were recorded but not attributed to bats were classified as NOISE.

\section{Data analysis}

Before statistical analysis, all mean values were checked and examined for normality using the Shapiro-Wilk test (Shapiro and Wilk 1965; $P=0.05$ ), and non-parametric analyses were conducted to confirm parametric results for any variables found to be non-normal. Differences 
among the three sites for pre- and post-treatment basal area, and post-treatment litter depth were examined with a one-way ANOVA (Fisher 1966). For posttreatment basal area, Tukey's Honestly Significant Difference (HSD; Tukey 1949) was used to detect significant differences among the means across sites when the ANOVA test was significant. Differences among the three sites for seedling densities (pre versus post treatment) were examined with a two-way (time $\times$ site) repeated measures ANOVA with bootstrapped nonparametric comparisons to examine the simple effects due to the non-normal distribution of the data. Simple effects were examined for time differences as well as by site because an interaction between site and time was found to be significant for the total seedling analysis and the oak seedling analysis (seedlings $P=0.03$; oak seedlings $P=0.04$ ).

To examine the effects of our treatments on tree seedling species diversity, we estimated the Shannon-Wiener Index (Shannon and Weaver 1949) using seedling densities from each plot at each site before the treatments were applied (pre treatment) and two years after the last fire (post treatment). Differences among the sites and treatments were analyzed with a two-way ANOVA with the Shannon-Wiener Index $(\mathrm{H})$ as the dependent variable. We did not estimate $\mathrm{H}$ for understory cover or overstory tree density because, in each case, we grouped species other than oak into categories during our inventories (e.g., graminoids, other hardwoods). We also examined differences for understory plant cover among sites $(n=3)$, between time (pre versus post treatment, $n=2)$, and among taxonomic groupings $(n=5)$ with a three-way ANOVA using arcsin transformed data. Post-treatment sapling densities were analyzed with a one-way ANOVA with sapling densities as the dependent variable and site as the independent variable $(n=3)$. Tukey's HSD was used to detect significant differences among the means when the ANOVA tests were significant.

When investigating distributional assumptions, we found that pre-treatment oak seedling density and oak seedling density following each fire was best modeled following the log-normal distribution, and residual subject-specific pseudo likelihood was used to estimate model parameters (Stroup 2012). Because oak seedling counts were taken in the same location over time, we modeled within-site variability using repeated measures with a first-order ante-dependence covariance structure (Stroup et al. 2018). For this analysis, oak seedling density was the dependent variable and time $(n=5)$ and site $(n=3)$ were the independent variables. Simple effects were further investigated using least squares means, because an interaction between site and time was found to be significant $(P=0.03)$. In order to control for Type I error, we used a Tukey adjustment. This analysis was performed using PROC GLIMMIX from SAS/STAT software Version 9.4 of the SAS system for Windows (SAS 2002-2012).

The relationship between post-treatment oak seedling densities and pre-treatment oak seedling densities, posttreatment total basal area, post-treatment oak basal area, and the number of oak trees $>20 \mathrm{~cm}$ dbh within ten meters of plot center was examined with simple linear regression (https://www.xlstat.com/en/). Differences in rodent captures from 2017 to 2019 were examined using a three-way ANOVA with rodents captured as the dependent variable and treatment (managed versus unmanaged forest, $n=2)$, site $(n=3)$, and year $(n=3)$ as independent variables. Tukey's HSD was used to detect significant differences among the means when the ANOVA test was significant. The 2019 bat activity in the treated stands and adjacent undisturbed forest were examined with a three-way ANOVA with bat passes per trap night as the dependent variable and site $(n=3)$, treatment $(n=2)$, and taxonomic groupings $(n=7)$ as the independent variables. For the bat analysis, bootstrapped nonparametric comparisons were used to examine the simple effects due to the non-normal distribution of the data.

\section{Results}

\section{Vegetation, litter depths, and browse}

There were no differences among the sites for total basal area, pine basal area, or oak basal area prior to harvest and prescribed burning treatments among the three sites (Table 1). After thinning and three prescribed fires, Site 1 had significantly lower total basal area and pine basal area than Site 3 (Table 2). The total number of seedlings on the three sites did not differ significantly before or after treatments, and sassafras had the highest seedling densities pre and post treatment (Fig. 2). Over the duration of the study, total oak seedling densities (white oak, black oak, scarlet oak, chestnut oak) rose $75 \%$, from $10200 \mathrm{ha}^{-1}$ to $17900 \mathrm{ha}^{-1}$ (Fig. 2), but there was no statistical difference between pre- and post-treatment densities $(P=0.16)$. After sassafras and oak, winged sumac (Rhus copallina L.), red maple, loblolly pine,

Table 1 Pre treatment basal area $\left(\mathrm{m}^{2} \mathrm{ha}^{-1} \pm\right.$ standard error) for oak restoration sites 1, 2, and 3 prior to thinning and burning on the southern Cumberland Plateau in southeastern Tennessee, USA (2009 to 2012)

\begin{tabular}{lrrrr}
\hline & \multicolumn{2}{c}{ Pre-treatment basal area $\left(\mathrm{m}^{2} \mathrm{ha}^{-1}\right)$} & \\
\cline { 2 - 4 } & \multicolumn{1}{c}{ Site 1 } & \multicolumn{1}{c}{ Site 2 } & \multicolumn{1}{c}{ Site 3 } & $P$-value \\
\hline All trees & $31.3 \pm 3$ & $33.3 \pm 5$ & $27.2 \pm 2$ & 0.44 \\
Pine & $6.9 \pm 2$ & $16.0 \pm 5$ & $7.1 \pm 3$ & 0.27 \\
Oak & $16.9 \pm 2$ & $12.4 \pm 3$ & $9.9 \pm 2$ & 0.08 \\
\hline
\end{tabular}


Table 2 Post treatment basal area $\left(\mathrm{m}^{2} \mathrm{ha}^{-1} \pm\right.$ standard error) for oak restoration sites 1, 2, and 3 on the southern Cumberland Plateau, Tennessee, USA (estimated in 2018, two years after the last fire at each site). Letters indicate differences among the sites (Tukey's HSD, $P \leq 0.05$ )

\begin{tabular}{lcccr}
\hline & \multicolumn{2}{c}{ Post-treatment basal area $\left(\mathrm{m}^{2} \mathrm{ha}^{-1}\right)$} & \\
\cline { 2 - 4 } & Site 1 & Site 2 & Site 3 & P-value \\
\hline All trees & $13.0 \pm 6 \mathrm{~b}$ & $12.8 \pm 8 \mathrm{ab}$ & $18.8 \pm 5 \mathrm{a}$ & 0.04 \\
Pine & $0.0 \pm 0 \mathrm{~b}$ & $3.2 \pm 5 \mathrm{ab}$ & $4.7 \pm 7 \mathrm{a}$ & 0.02 \\
Oak & $11.8 \pm 6 \mathrm{a}$ & $9.6 \pm 7 \mathrm{a}$ & $8.0 \pm 6 \mathrm{a}$ & 0.15 \\
\hline
\end{tabular}

yellow-poplar, and sourwood had the highest densities post treatment (Fig. 2). Seedling responses to treatments varied greatly among the three sites; for example, sassafras density was greatly decreased over the duration of the study in Site 2 but increased greatly at Site 3 (Fig. 3). In addition, oak density increased over time in Sites 1 and 2 but decreased at Site 3 (Fig. 3). When examined separately by site, the four oak species responded differently, with scarlet oak being the only oak species to increase in density over time at all three sites (Fig. 4). Chestnut oak had the largest increases in density at Sites 1 and 2, while black oak decreased in density over time at all three sites (Fig. 4). Because chestnut oak was missing from the overstory at Site 3, we did not find any chestnut oak seedlings at this site during the study. Scarlet oak was the only oak species to have a statistically higher post-treatment mean compared to the pre-treatment mean $(P=0.001)$, while chestnut oak $(P=0.16)$, white oak $(P=0.60)$, and black oak $(P=0.20)$ did not have significantly different post-treatment mean densities (two years after the last fire).

Our pre-treatment estimates of tree seedling species diversity using the Shannon-Wiener Index $(\mathrm{H})$ ranged from 0.54, 0.55, and 1.06 at Sites 1, 2, and 3, respectively, and these values rose to 1.12, 1.22, and 1.4, respectively, during our post-treatment inventory (two years after the last fire). Post-treatment values for $\mathrm{H}$ were higher in $82 \%$ of the sampling plots at Site 1, 60\% of the plots at Site 2, and 36\% of the plots at Site 3. Seedlings of 16 tree species were present among the three sites pre treatment, and 17 species were present during post treatment. We note that the fire treatments at Site 3 eliminated the eastern white pine seedlings that were present during our pre-treatment inventories. Two years after the last fire, the species with the highest $\mathrm{H}$ included sassafras, white oak, and chestnut oak at Site 1; sassafras, scarlet oak, and winged sumac at Site 2; and sassafras, black oak, and yellow-poplar at Site 3. Mean posttreatment $\mathrm{H}$ for tree seedlings $(1.15 \pm 0.06)$ was significantly higher $(P \leq 0.001)$ compared to the pre-treatment value $(0.74 \pm 0.07)$.

We also examined changes in total oak seedling densities following thinning and each fire at each permanent plot, and our repeated measures analysis indicated that there were no significant differences among the three sites following all the fires (Table 3). The only meaningful differences between oak seedling densities occurred at Site 1. Within Site 1, we found that, after the first fire, the oak seedling densities were significantly lower than the densities after the second fire, the third

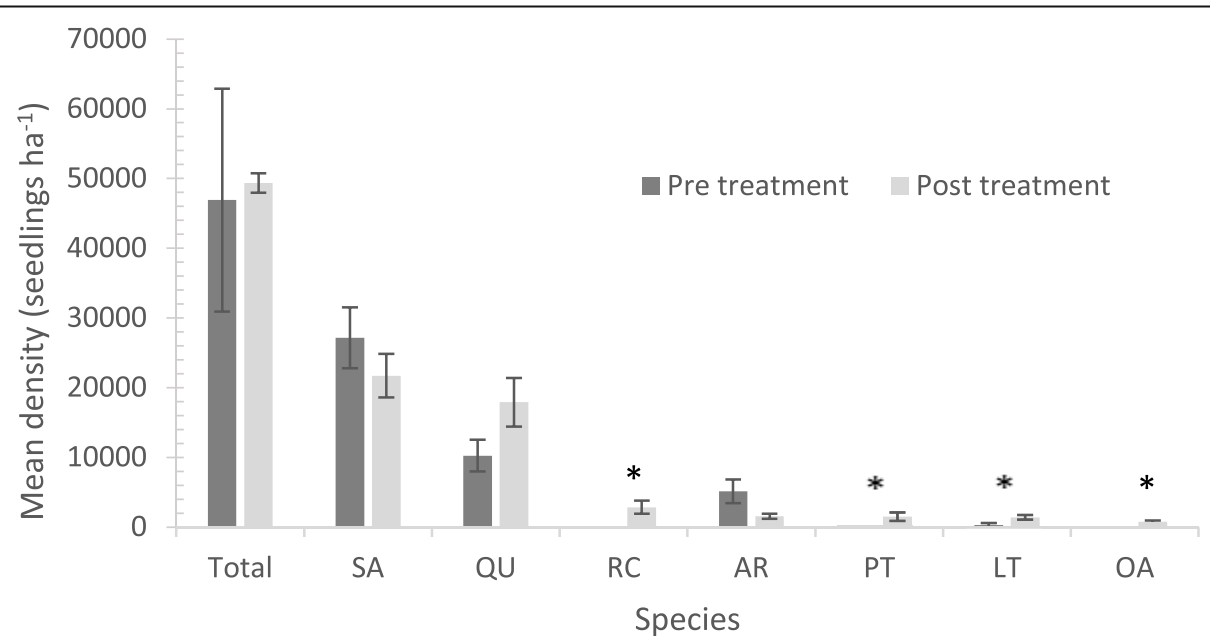

Fig. 2 Mean seedling densities (seedlings $h^{-1}$ ) prior to treatment (2009 to 2012) and two years after the last prescribed fire (2018) for all seedlings and the seven most abundant species (post treatment) at the three oak restoration study sites on the southern Cumberland Plateau, Tennessee, USA. The height of the bar is the mean, and the whiskers at the end of each bar represent 1.0 standard error. $\mathrm{SA}=$ sassafras, $\mathrm{QU}=$ Quercus spp., $\mathrm{RC}=$ winged sumac, $\mathrm{AR}=$ red maple, PT = loblolly pine, $\mathrm{LT}=$ yellow-poplar, $\mathrm{OA}=$ sourwood. Asterisks $\left(^{*}\right)$ indicate significant difference $(P \leq 0.05)$ between pre-and post-treatment values for winged sumac, loblolly pine, yellow-poplar, and sourwood. The P-values were estimated from a bootstrapped non-linear regression analysis. We did not detect any significant differences in pre- versus post-treatment densities for total seedlings or the other species 


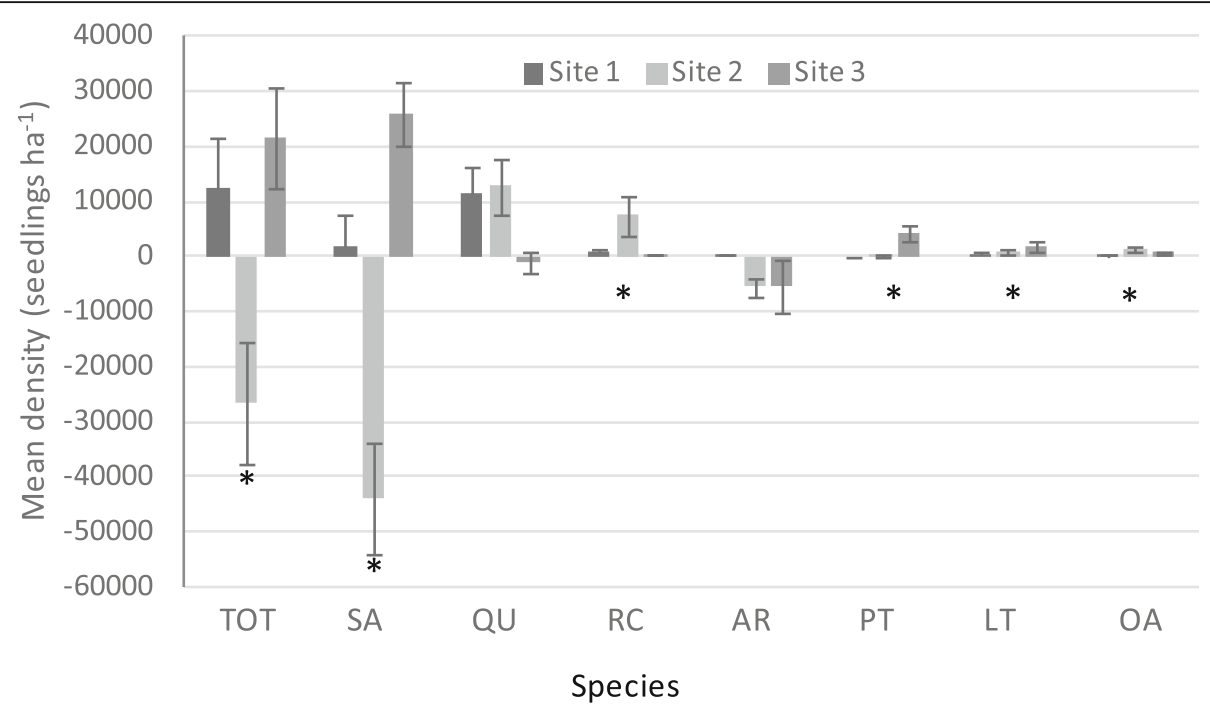

Fig. 3 The average difference between mean tree seedling densities (pre treatment versus post treatment) by site for all seedlings, and the seven most abundant species (post treatment) at the three oak restoration study sites on the southern Cumberland Plateau, Tennessee, USA (2009 to 2018). The height of the bar is the average difference between means, and the whiskers at the end of each bar represent 1.0 standard error. $\mathrm{SA}=$ sassafras, $\mathrm{QU}=$ Quercus spp., $\mathrm{RC}=$ winged sumac, $\mathrm{AR}=$ red maple, $\mathrm{PT}=$ loblolly pine, $\mathrm{LT}=$ yellow-poplar, $\mathrm{OA}=$ sourwood. Asterisks $\left({ }^{*}\right)$ indicate significant site effect $(P \leq 0.05)$

fire, and two years following the last fire (Table 3). However, the differences in comparison to all other sites and time points were not significant. Using simple liner regression, we found that post-treatment oak seedling densities were significantly related to pre-treatment oak seedling densities $\left(\mathrm{R}^{2}=0.55, P<0.0001\right.$; Fig. 5). Total oak basal area $\left(R^{2}=0.11, P=0.03\right)$ and the number of oak trees $>20 \mathrm{~cm}$ dbh within $10 \mathrm{~m}$ of plot center $\left(\mathrm{R}^{2}=0.15, P=0.01\right)$ were also significantly related to post-treatment oak seedling densities.
Following tree thinning at the restoration sites, we did not detect any saplings (heights $>1.3 \mathrm{~m}$ ) in our permanent plots until two years after the last fire (in 2018). During this inventory, winged sumac, sassafras, sourwood, and black locust (Robinia pseudo-acacia L.) had the highest mean sapling densities across the three sites (Fig. 6). We detected a significant site effect for sapling densities $(P=0.04)$, and Site 2 had higher densities than Sites 1 and 3, largely due to the presence of winged sumac $\left(1700 \mathrm{ha}^{-1}\right)$ and sassafras $\left(1000 \mathrm{ha}^{-1}\right)$. Two years after the last fire, sapling densities

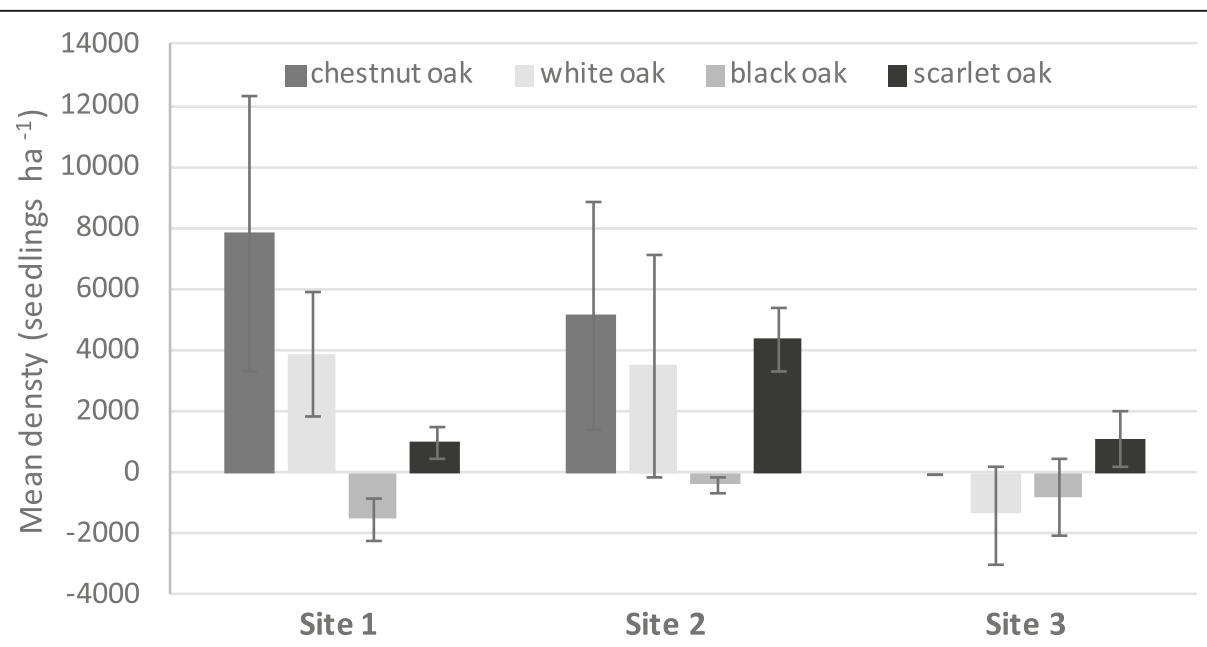

Fig. 4 The average difference between mean oak seedling densities (pre treatment versus post treatment) by site at the three oak restoration study sites on the southern Cumberland Plateau, Tennessee, USA (2009 to 2018). The height of the bar is the average difference between means, and the whiskers at the end of each bar represent 1.0 standard error. Scarlet oak was the only oak species to have a significantly higher posttreatment mean compared to its pre-treatment mean $(P=0.001)$, and there was a significant site effect for scarlet oak and chestnut oak $(P \leq$ 0.05) using bootstrapped nonparametric comparisons 
Table 3 Mean pre- and post-treatment oak seedling densities ( \pm 1 standard deviation) from 2009 to 2018 among oak restoration sites 1, 2, and 3 on the southern Cumberland Plateau, Tennessee, USA. The P-values were estimated using a repeated measures analysis with a first-order ante-dependence covariance structure (with 95\% confidence levels). At Site 1, oak seedling densities after the first fire were significantly different from the other time periods $(P \leq 0.05)$. All other comparisons were not significantly different

\begin{tabular}{|c|c|c|c|c|}
\hline & \multicolumn{3}{|c|}{ Mean density (oak seedlings ha ${ }^{-1}$ ) } & \multirow[b]{2}{*}{$P$-value } \\
\hline & Site 1 & Site 2 & Site 3 & \\
\hline Pre treatment & $16563 \pm 17151$ & $3952 \pm 6199$ & $10232 \pm 15035$ & 0.16 \\
\hline After first fire & $11332 \pm 17423$ & $8398 \pm 12049$ & $8292 \pm 7416$ & 0.27 \\
\hline After second fire & $26174 \pm 34240$ & $14200 \pm 13513$ & $8571 \pm 11168$ & 0.22 \\
\hline After third fire & $45352 \pm 61774$ & $13900 \pm 13739$ & $7642 \pm 9017$ & 0.60 \\
\hline $2 \mathrm{yr}$ after last fire & $27823 \pm 30412$ & $16700 \pm 13441$ & $9214 \pm 11583$ & 0.44 \\
\hline
\end{tabular}

for all species were considerably lower than for seedling densities, and we plan to exclude fire from these sites over the next ten years to recruit oak seedlings into the sapling phase.

The percent cover for tree seedlings and for the grasses (primarily Dichanthelium (Hitchc. and Chase) Gould spp. and Andropogon virginicus L.) was significantly higher following our treatments (Fig. 7; $P<0.0001$ ). We also detected a significant effect $(P<0.05)$ for taxonomic grouping as well as for site $\times$ time and time $\times$ taxonomic grouping interactions. There were no significant differences among the three sites for total understory plant cover. In 2016 (after the last fire), mean litter depths ranged from 0.4 to $1.2 \mathrm{~cm}$ and there was no statistical difference for total $\mathrm{O}$ horizon depths (to mineral soil) among the three sites $(P=0.16)$. Two years after the last fire, deer browse of oak seedlings was light (documented in $<10 \%$ of the subplots), and Vaccinium spp., Smilax spp., and sassafras were the preferred species for deer browse across all study sites.

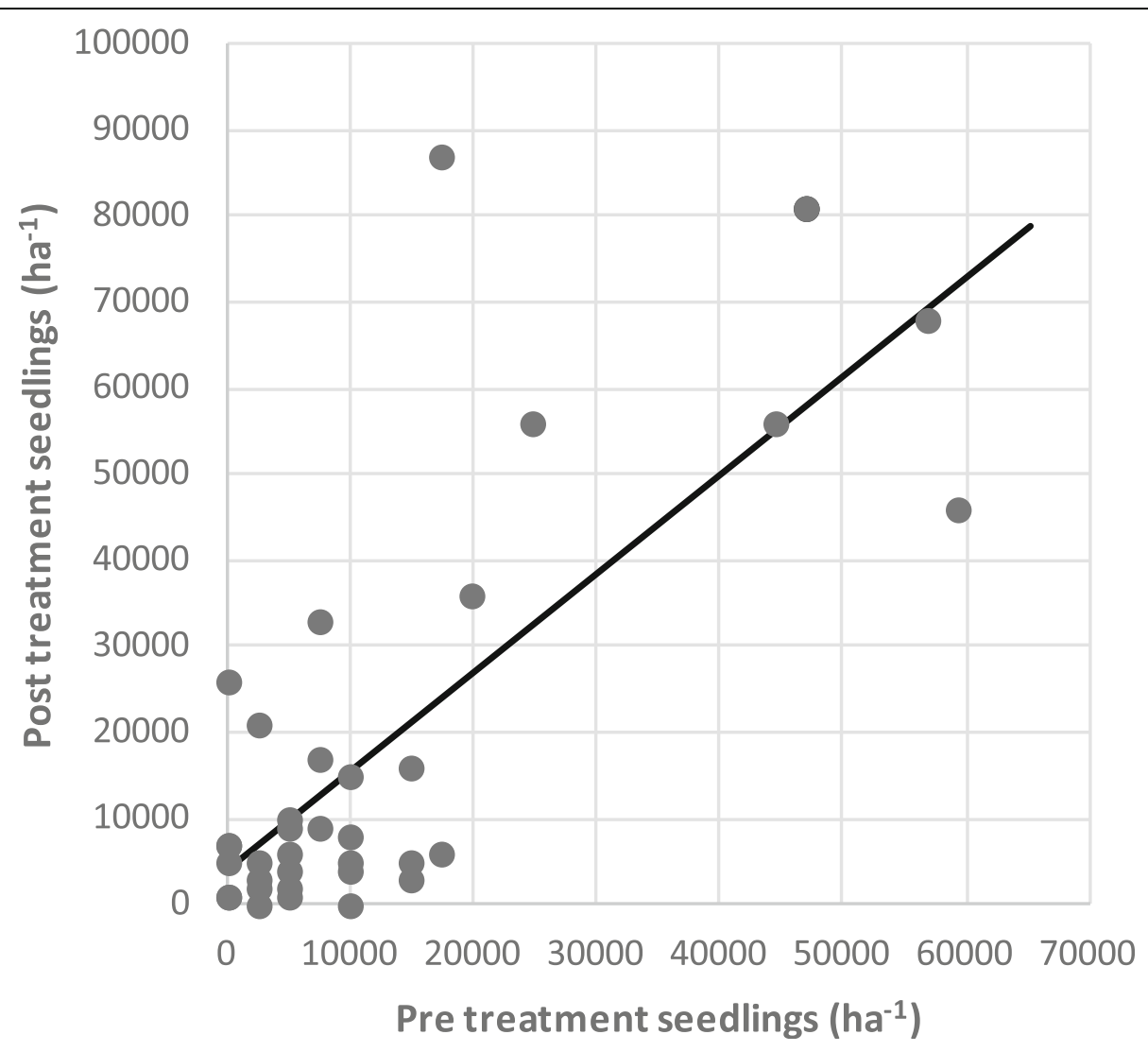

Fig. 5 Regression of post-fire oak seedlings (per hectare) by pre-treatment oak seedlings (per hectare, $R^{2}=0.55, P<0.0001$ ) from the three oak restoration study sites on the southern Cumberland Plateau, Tennessee, USA (2009 to 2018). The equation of the model is $y=4202.80+(1.1464) x$ 


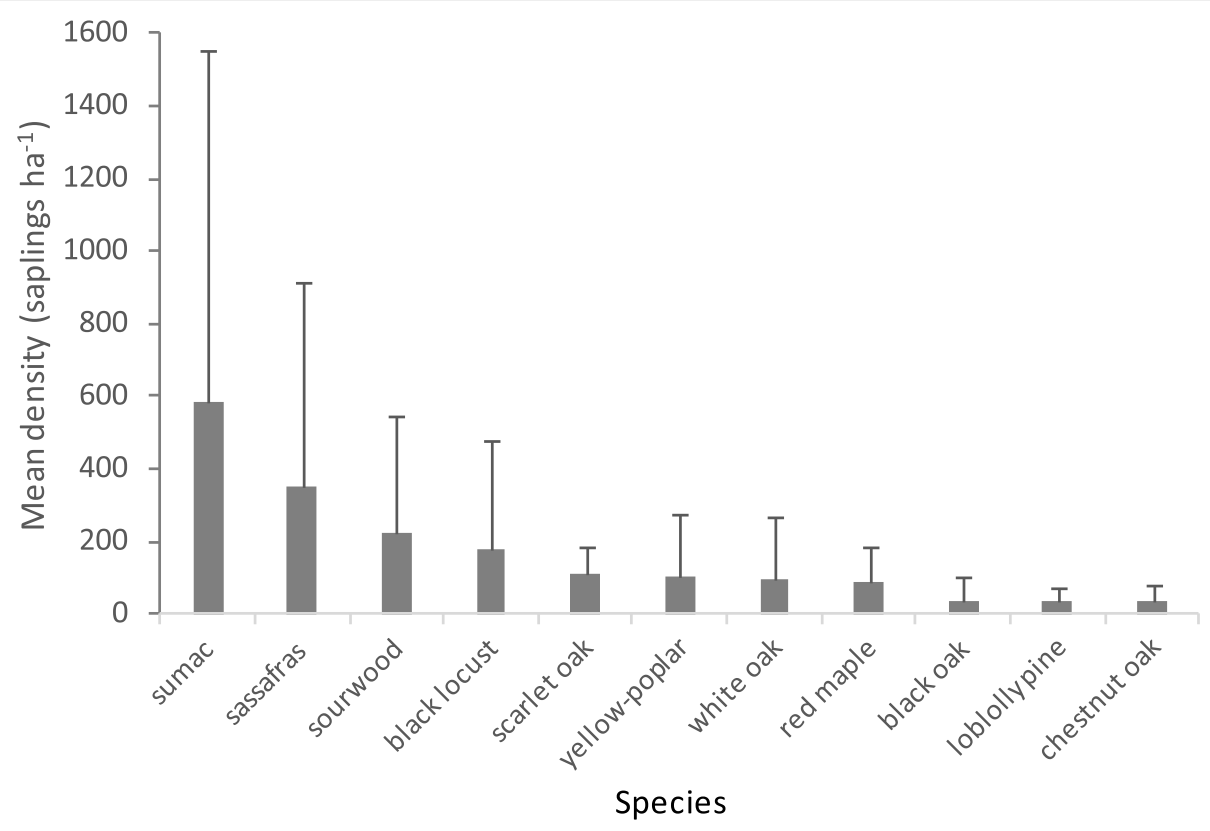

Fig. 6 Mean sapling densities among the three oak restoration sites on the southern Cumberland Plateau, Tennessee, USA, two years after the last prescribed fire (2018). The height of the bar is the mean, and the whiskers at the end of each bar represent 1.0 standard deviation. Saplings had heights $>1.3 \mathrm{~m}$

\section{Mammals}

Monitoring of rodents did not indicate a clear habitat preference between treated sites and adjacent unmanaged forest (Fig. 8). In 2017, three species were trapped in the treated sites: the white-footed mouse
(Peromyscus leucopus Rafinesque), the deer mouse (Peromyscus maniculatus Wagner), and the Hispid cotton rat (Sigmodon hispidus Say and Ord). Two species (the white-footed and deer mouse) were trapped in the forest control. In 2018, only one

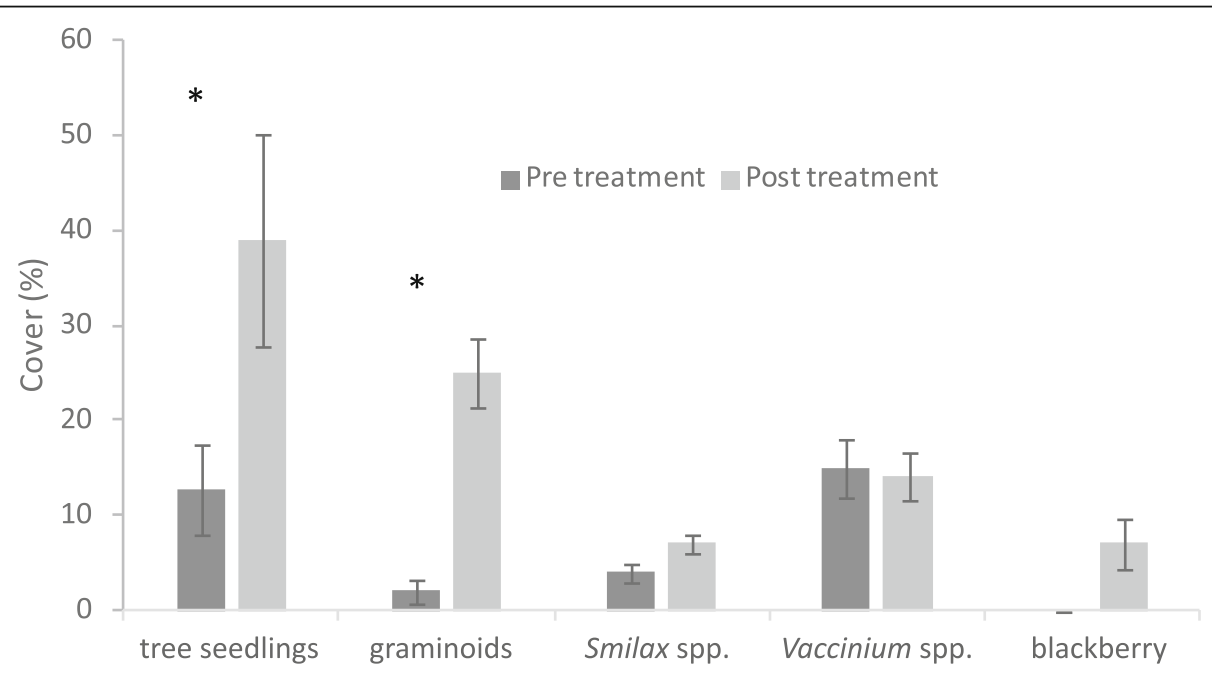

Species

Fig. 7 Pre- and post-treatment cover for tree seedlings, graminoids, Smilax spp., Vaccinium spp., and blackberry at the three oak restoration sites on the southern Cumberland Plateau, Tennessee, USA (2009 to 2018). The height of the bar is the percent cover, and the whiskers at the end of each bar represent 1.0 standard error. Asterisks $\left(^{*}\right)$ indicate significant time effect (post treatment $>$ pre treatment, $P \leq 0.001$ ) for tree seedling and graminoid cover 


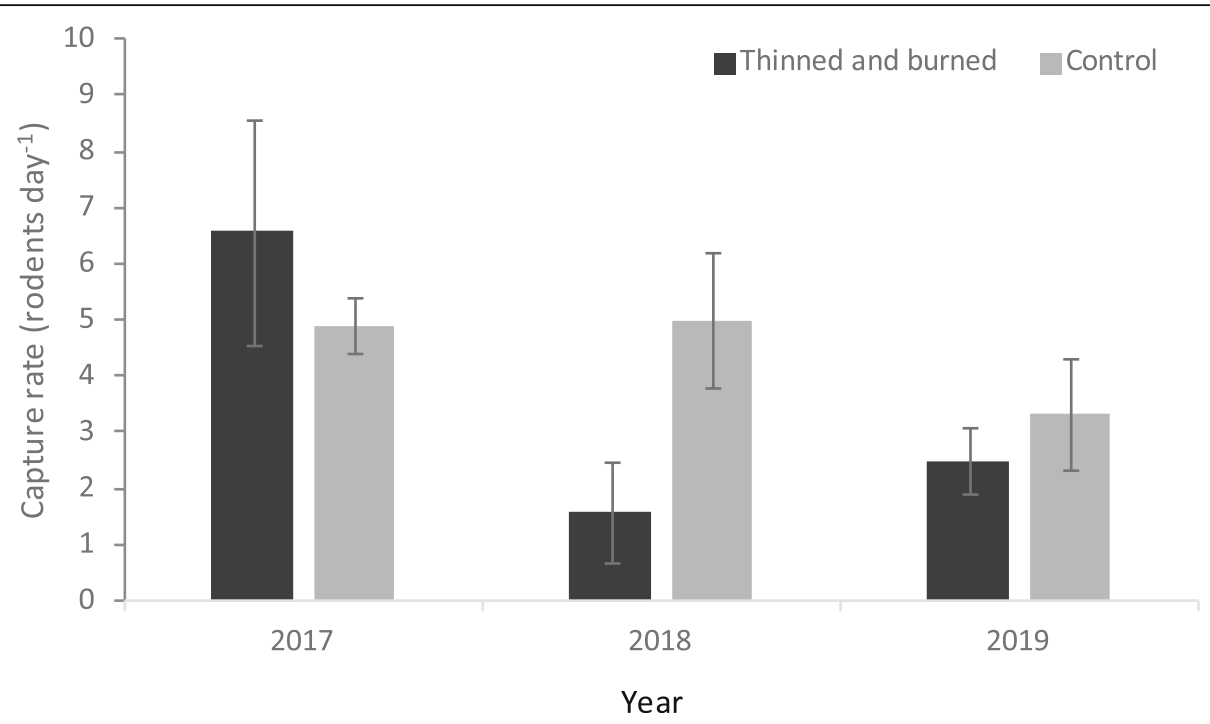

Fig. 8 Mean rodent captures from 2017 to 2019 from the three oak restoration study sites and three adjacent unmanaged forest controls on the southern Cumberland Plateau, Tennessee, USA. The height of the bar is the mean, and the whiskers at the end of each bar represent 1.0 standard error. The only year with a significant difference between the treated sites and untreated controls was $2018(P=0.001)$. There were no significant differences by site in this analysis

species (white-footed mouse) was trapped in both site types. In 2019, four species-the white-footed mouse, deer mouse, cotton mouse (Peromyscus gossypinus LeConte), and the eastern chipmunk (Tamias striatus L.)-were trapped in the treated sites, while two species were trapped in the forest controls (white-footed mouse and cotton mouse). In our analysis, there were no significant differences for rodents trapped per day by site, but we did detect a significant difference for year $(P=0.001)$ and treatment $(P=0.001)$, as well as a year $\times$ treatment effect $(P=0.002)$. The only year with a significant difference for mean rodent captures between the treated and untreated forest was in 2018 (Fig. 8). Among the years studied, there was a significantly higher number of captures in 2017 compared to 2018 and 2019.

The large-bodied bats including big brown bats and silver-haired bats (EPFU/LANO), eastern red bats and evening bats (LABO/NYHU), and hoary bat (LACI) each had higher mean observations per trap night in the treated sites compared to forest controls $(P \leq 0.01$; Table 4). The smaller bodied bats (five species of $M y$ otis) and tri-colored bat (PESU) had low numbers of observations in both site types, which could be attributed to range-wide declines caused by white-nose syndrome (Ingersoll et al. 2016). As with the larger bodied bats, MYOTIS and PESU had significantly higher activity in the treated sites (Table 4). There were only two observations for CORA, thus we excluded it from our analysis. The noise levels at the treated sites were significantly higher than the control sites during our sampling period, likely due to the activity of cicadas (Magicicada Davis spp.) and tree frogs (Hyla Laurenti spp.).

\section{Discussion}

Residual trees, fire behavior, and skidding technology Patterns of oak regeneration in our study reflected the mixed results of prior work in thinned and unthinned oak stands that were subsequently burned using

Table 4 Mean number of bat passes per trap night ( \pm standard error) from June to August 2019 from oak restoration sites 1, 2, and 3 and three unmanaged forest controls on the southern Cumberland Plateau, Tennessee, USA. The larger-bodied bat species are listed in bold. P-values were estimated with a threeway ANOVA with bootstrapped nonparametric comparisons

\begin{tabular}{lccr}
\hline & \multicolumn{2}{c}{ Mean number of bat passes per trap night } & \\
\cline { 2 - 3 } & Thin and burn & Control & P-value \\
\hline EPFU/LANO $^{1}$ & $200.2 \pm 18.5$ & $6.9 \pm 25.9$ & 0.001 \\
LABO/NYHU $^{2}$ & $80.6 \pm 8$ & $2.4 \pm 14.7$ & 0.001 \\
LACI $^{3}$ & $17.2 \pm 2.3$ & $4.9 \pm 3.6$ & 0.005 \\
MYOTIS $^{4}$ & $8.3 \pm 0.8$ & $2.6 \pm 1.3$ & 0.001 \\
PESU $^{5}$ & $10.5 \pm 1.4$ & $1.3 \pm 3.0$ & 0.007 \\
NO ID $^{6}$ & $96.6 \pm 6.1$ & $9.2 \pm 7.3$ & 0.001 \\
Noise $^{7}$ & $1206.7 \pm 73.7$ & $310.7 \pm 73.3$ & 0.001 \\
\hline
\end{tabular}

${ }^{1}$ EPFU/LANO = big brown bat and silver-haired bat

${ }^{2} \mathrm{LABO} / \mathrm{NYHU}=$ eastern red bat and evening bat

${ }^{3} \mathrm{LACl}=$ hoary bat

${ }^{4}$ MYOTIS = southeastern bat, gray bat, northern long-eared bat, Indiana bat, and little brown bat

${ }^{5}$ PESU $=$ tri-colored bat

${ }^{6} \mathrm{NO} I \mathrm{ID}=$ calls recorded but unidentified

${ }^{7} \mathrm{NOISE}=$ sounds recorded but not attributed to bats 
prescribed fire (Brose et al. 2012). In this study, Sites 1 and 2 experienced an increase of oak seedlings by 11000 and $12000 \mathrm{ha}^{-1}$, respectively (Table 3). Both of these sites experienced at least one fire of moderate intensity (flame lengths up to $3 \mathrm{~m}$ ) more than one year after harvest, which may have contributed to this success. In addition, the post-treatment forest composition at Sites 1 and 2 had a larger residual oak component (91 and 75\% of total basal area, respectively) compared to Site 3 (42\%), which had lower oak seedling recruitment. Across all three sites, oak regeneration was highly variable, and at our 41 permanent seedling plots, only two did not have any oak seedlings at the end of our study. We also noted that, at Site 1, which had the highest number of oak seedlings post treatment, the residual overstory contained all four oak species examined in this study. Site 2 lacked black oak and Site 3 did not have any chestnut oak in the overstory. Because 2012 and 2014 were good mast years for white oak and chestnut oak in this region, the lack of chestnut oak mast in Site 3 likely contributed to the lower observed oak recruitment. Of special note, after the three fires, red maple and yellow-poplar seedling densities were much lower compared to oak at our sites (Fig. 2).

This study differed from many previous oak-fire studies because the initial stands had a planted pine component, common to some private lands, which was targeted for removal at each site. Following the first fire at Site 1, loblolly pine regeneration was widespread. The second fire at this site was of moderate intensity and consumed almost 100\% of these loblolly seedlings and saplings, resulting in higher flame lengths. The other sites did not experience a large pulse of loblolly pine regeneration following the harvest. As previously mentioned, Sites 2 and 3 had a large number of eastern white pine saplings in the understory prior to treatments, and the thinning operations, the three fires, and manual cutting of the surviving stems eliminated the species from those two sites. As previously mentioned, small patches of shortleaf pine were left at Sites 2 and 3 because it is a native pine species that was largely removed from the landscape 100 years ago, and the land manager did not want to remove it because it is now rare on the property. Leaving this pine created differences between sites 1 and 3 for post-treatment basal area, but our overall reductions in basal area were within the guidelines from prior studies. It is our feeling that the post-treatment pine basal area, ranging from 3 to $5 \mathrm{~m}^{2} \mathrm{ha}^{-1}$, did not significantly alter the results of our study.

We also note that logging and skidding technology greatly affected burn coverage, fire intensity, and fire residence time during the first post-harvest prescribed fire. Site 2 was logged with a forwarder and processor, and the 10- and 100-hour fuels were evenly distributed across the site after the harvest. This pattern of logging- slash distribution resulted in a homogenous and moderate fire across the site during the first fire, although skid trails did interrupt fire spread in some locations. At the other two sites, a grapple skidder redistributed tree tops throughout the sites after tree processing at the landings, and this resulted in a much more heterogeneous pattern of slash distribution and fire behavior during the first fires. The choice of equipment for treatments is often not at the discretion of small private landowners, but should be monitored and reported for future work.

Although we did not quantify percent cover, we remarked that dog fennel (Eupatorium capillifolium Lam.) and Japanese stilt grass (Microstegium vimineum Trin.) spread following use of fire at Sites 1 and 2. Dog fennel was not present on any of the sites prior to treatments and, over time, it dominated cover on the highly disturbed skid trails and log landings, and it excluded previously established warm-season grasses after the second and third fires. Prior to treatments, Japanese stilt grass was present in very small patches that doubled or tripled in size over the three fires. Previous work has indicated that dog fennel potentially has allelopathic qualities for tree seedlings and other plants (Hollis et al. 1982; Smith 1990) and that Japanese stilt grass increased fire intensity to the detriment of native plants (Emery et al. 2011; Brewer et al. 2015). We noted that shadeintolerant tree species such as black locust began to occupy these sites after we stopped fire treatments, but for managers intending to use fire as a long-term tool, the frequent use of fire may contribute to the spread of these two species on the most disturbed portions of managed sites.

\section{A comparison with prior studies using thinning and fire}

Many of the studies that examined the role of fire in regenerating oak have occurred in stands that were not mechanically thinned (Arthur et al. 1998; Hutchinson et al. 2005; Blankenship and Arthur 2006; Green et al. 2010; Hutchinson et al. 2012). In stands that were thinned and exposed to one or more fires post harvest, restoration trajectories were complex. For example, Albrecht and McCarthy (2006) reported that one prescribed fire immediately following a 20 to $30 \%$ basal area reduction resulted in little benefit for oak regeneration, and that red maple stump sprouts were very prevalent in their research sites. Cannon and Brewer (2013) and Brewer (2015) found better growth responses of resprouting oaks compared to resprouting non-oaks in an open-canopy forest exposed to three low-intensity fires over a five-year time period. In their review of oakfire studies, Brose et al. (2012) indicated that prescribed fire improved the chances of increasing oak regeneration when fires were applied during the growing season and several years after basal area reductions. In oak stands in 
central Virginia, USA, Brose and Van Lear (1998) reduced basal area to 11.5 to $14.0 \mathrm{~m}^{2} \mathrm{ha}^{-1}$ (with residual oak $>50 \%$ of total basal area), and reported that moderate- to high-intensity fires resulted in high mortality of red maple and yellow-poplar, and increased oak regeneration at their experimental sites. In a follow-up to the 1998 work in central Virginia, Brose et al. (1999) emphasized the importance of waiting several years before applying the first fire post harvest. They also suggested that low-intensity fires were less likely to affect oak competitors, and that moderate- to high-intensity spring fires were more likely to benefit oak regeneration when combined with mechanical thinning. Based on their findings, the three low-intensity fires at Site 3 may have contributed to the lower number of oak seedlings that established over time.

Additional studies have supported the idea of applying prescribed fire several years after a mechanical thinning to allow oak seedlings to outcompete shade-tolerant species. For example, in Wisconsin, USA, Kruger and Reich (1997) reduced basal area to 15 to $30 \mathrm{~m}^{2} \mathrm{ha}^{-1}$, and applied two prescribed fires (spring fires) four years after the harvest. They reported reduced densities of potential red oak competitors, and indicated that oak seedling growth improved after the fires. More recently, Iverson et al. (2017) published results from a 13-year study that included sites that were thinned to basal areas of 19 to $23 \mathrm{~m}^{2} \mathrm{ha}^{-1}$ and exposed to three prescribed fires. Over the duration of the study, they reported an 18-fold increase in large oak and hickory seedlings while yellowpoplar and red maple seedlings decreased. In this study, their first fire was of low intensity (applied 1.5 years after harvest), and the second and third fires were of moderate intensity (applied 5.5 year and 10.5 years after harvest, respectively). Two years after our third fire, we saw similar results with a $75 \%$ increase in oak seedlings, from $10200 \mathrm{ha}^{-1}$ to $17900 \mathrm{ha}^{-1}$ (average for three sites), and much lower seedling densities for red maple and yellowpoplar (1551 and 1390 seedlings ha ${ }^{-1}$, respectively). As previously mentioned, we did not detect a statistically significant rise in oak seedling densities from pre treatment to post treatment $(P=0.16)$, but a $75 \%$ increase in oak seedlings does have management implications and will hopefully result in improved oak recruitment into the midstory in the coming years as we halt the use of fire on these sites.

\section{Mammal monitoring}

The results of our bat monitoring were similar to other studies conducted on the Allegheny Plateau, the Cumberland Plateau, and southern Appalachian sites (Titchenell et al. 2011; Dodd et al. 2012; Cox et al. 2016). Over our monitoring period, big brown bats and silver-haired bats had much higher activity in the thinned and burned sites (200 mean passes per night) compared to our forest controls (7 passes). Eastern red bats and evening bats were also recorded with substantially higher bats passes per evening in the treated forest compared to the controls (81 to 2 , respectively). We do note that higher mean bat passes per night may not always equate with increased abundance because it is possible that a small number of bats foraged regularly on the site and were recorded repeatedly.

As previously mentioned, Cox et al. (2016) monitored bat activity in stands on the Cumberland Plateau that were exposed to various levels of mechanical thinning and fire, and they reported higher bat activity in stands with the lowest basal areas. They stated that the combined thinning and fire treatments had reduced midstory clutter, which improved foraging conditions for bats at those sites. On the Allegheny Plateau, Titchenell et al. (2011) monitored bat activity in upland oak-hickory forests where basal area had been reduced by 30 to $50 \%$. They found that bats preferred the harvested sites over the undisturbed forest controls, and that red bats, big brown bats, and silver-haired bats were detected at the highest numbers. They indicated that woody volume at 3 to $6 \mathrm{~m}$ above the ground played a large role in bat activity for several species. Across four Appalachian sites, Dodd et al. (2012) reported lower total bat activity in undisturbed forest (basal area of $27 \mathrm{~m}^{2} \mathrm{ha}^{-1}$ ) compared to forest exposed to mechanical thinning (basal areas of 8 to $22 \mathrm{~m}^{2} \mathrm{ha}^{-1}$ ). These authors suggested establishing patches of varied disturbance across the landscape to benefit bats and their prey.

Our forest treatments clearly reduced midstory clutter (through thinning and fire) and, although we did not report snag densities in this study, fire treatments did kill several residual oak trees at each experimental site, particularly after the first fires. This mortality potentially provided additional habitat for bat species, particularly Myotis species that utilize snags with peeling bark for summer roosting and to support maternal colonies (Menzel et al. 2000; Lacki et al. 2009). One year after the first fires, we observed peeling bark on many of the snags created by those fires. In addition, the disturbance created by thinning and use of prescribed fire led to the recruitment of the shade-intolerant black locust, which is known to provide suitable roosting habitat for northern long-eared bats as well as other bats species in central Appalachian hardwood forests (Menzel et al. 2002).

Although small mammals could potentially be negatively affected by management practices that alter amounts of woody debris, leaf litter depths, and the availability of food, Raybuck et al. (2012) reported that prescribed fire and thinning did not lower species richness or abundance for shrews (Sorex Linnaeus spp.) in upland oak forests in North Carolina. In our study, we 
began monitoring rodent activity a year following our last prescribed fire, and 2018 was the only year we observed differences in rodent activity between the forest control and our treated sites. In thinned and burned stands in Arizona, USA, deer mice responded favorably to thinning and fire, and Converse et al. (2006) recommended the retention of slash in managed sites for the benefit of small mammals. In longleaf pine (Pinus palustris Mill.) stands in Georgia, USA, that were exposed to prescribed fire, Conner et al. (2011) remarked that prescribed fires created low-quality habitat for cotton rats (Sigmodon hispidus Say and Ord) immediately after the fire, leading to increased predation at the burned sites.

\section{Conclusions}

In summary, the restoration of these oak-hickory habitats was highly variable following partial conversion of these sites to pine. The residual canopy of oaks, the timing of mast, and interactions with subsequent prescribed fire complicated predictable outcomes. While the use of repeated fire post harvest produced a forest resilient to recolonization by mesic species, the diversity of the oakhickory woodlands is clearly expressed in the stand-level variation of seedling responses observed in this study. The forest thinning and subsequent prescribed fires greatly reduced forest midstory clutter over time, and several species of bats preferred to forage in these sites compared to unmanaged forest controls with higher basal areas. Our three-year summer monitoring of rodent activity following the last of the three prescribed fires in 2016 revealed differences in rodent activity between our treated sites (1.5 captures per trap day) and adjacent forest controls (5.0 captures per trap day) only during $2018(P=0.001)$. If the restoration of thousands of hectares of converted pine stands continues in the southern Cumberland Plateau, land managers can use these results and those of prior studies to predict management outcomes for oak seedling densities as well as the effects that restoration efforts may have on nongame wildlife species.

\section{Acknowledgements}

The authors would like to thank E. Fowler, V. Schnaufer, J. Mulloy, E. Walker, C. Johnson, B. Ward, M. Kochinski, E. Whitmore, A. Fox, H. Bonner, and C. Crews for helping us collect field data while they were students at Sewanee. We also thank R.M. Paulson, Ph.D., of Elite Research, LLC, and S. Pokswinski of Tall Timbers for consultation with statistics presented in this paper.

\section{Authors' contributions}

KS designed the study, participated in the prescribed fires and preparation of the mechanical thinning, collected the vegetation data, and analyzed the data presented in the paper. AT collected the bat and rodent data and contributed to the writing of the manuscript. $\mathrm{KH}$ supervised the prescribed fires and contributed to the writing of the manuscript. JG contributed to the statistical analysis and writing of the manuscript. NW supervised the prescribed fires and supervised the thinning operations. NN collected field data, participated in the prescribed fires, and managed field crews that collected field data. All authors read and approved the final manuscript.
Funding

Funding for this research was provided by the Department of Earth and Environmental Systems and the Office of Environmental Stewardship and Sustainability at The University of the South.

\section{Availability of data and materials}

The datasets used or analyzed during the study are available from the corresponding author upon request.

\section{Ethics approval and consent to participate}

For the rodent trapping, we followed suggested guidelines for the use of wild animals in research as suggested by the Institute of Animal Care and Use Committee of The University of the South (permits Turner 9-2017, Turner 1-2018, and Turner 6-2019) and the American Society of Mammalogists (Sikes and Gannon 2011).

\section{Consent for publication}

Not applicable.

\section{Competing interests}

The authors declare that they have no competing interests.

\section{Author details}

${ }^{1}$ Department of Earth and Environmental Systems, The University of the South, 735 University Avenue, Sewanee, Tennessee 37383, USA. ${ }^{2}$ The Office of Environmental Stewardship and Sustainability, The University of the South, 735 University Avenue, Sewanee, Tennessee 37383, USA. ${ }^{3}$ Wildland Fire Scientist, Tall Timbers Research Station \& Land Conservancy, 13093 Henry Beadel Drive, Tallahassee, Florida, USA. ${ }^{4}$ Department of Mathematics and Computer Science, The University of the South, 735 University Avenue, Sewanee, Tennessee 37383, USA.

Received: 9 December 2019 Accepted: 29 July 2020

Published online: 09 September 2020

\section{References}

Abrams, M.D. 1992. Fire and the development of oak forests. BioScience 42: 346353. https://doi.org/10.2307/1311781.

Albrecht, M.A., and B.C. McCarthy. 2006. Effects of prescribed fire and thinning on tree recruitment patterns in central hardwood forests. Forest Ecology and Management 226: 88-103. https://doi.org/10.1016/j.foreco.2005.12.061.

Arthur, M.A., H.D. Alexander, D.C. Dey, C.J. Schweitzer, and D.L. Loftis. 2012. Refining the oak-fire hypothesis for management of oak-dominated forests of the eastern United States. Journal of Forestry 110: 257-266. https://doi.org/ 10.5849/jof.11-080.

Arthur, M.A., R.D. Paratley, and B.A. Blankenship. 1998. Single and repeated fires affect survival and regeneration of woody and herbaceous species in an oakpine forest. Journal of the Torrey Botanical Society 125: 225-236. https://doi. org/10.2307/2997220.

Artman, V.L., E.K. Sutherland, and J.F. Downhower. 2001. Prescribed burning to restore mixed- oak communities in southern Ohio: effects on breeding-bird populations. Conservation Biology 15: 1423-1434. https://doi.org/10.1046/j. 1523-1739.2001.00181.x.

Austin, L.V., A. Silvis, W.M. Ford, M. Muthersbaugh, and K.E. Powers. 2018. Bat activity following restoration prescribed burning in the central Appalachian upland and riparian habitats. Natural Areas Journal 38: 183-196. https://doi. org/10.3375/043.038.0208.

Bernard, R.F., and G.F. McCracken. 2017. Winter behavior of bats and the progression of white-nose syndrome in the southeastern United States. Ecology and Evolution 7: 1487-1496. https://doi.org/10.1002/ece3.2772.

Blankenship, B.A., and M.A. Arthur. 2006. Stand structure over 9 years in burned and fire-excluded oak stands on the Cumberland Plateau, Kentucky. Forest Ecology and Management 225: 134-145. https://doi.org/10.1016/j.foreco.2005. 12.032.

Brewer, J.S. 2015. Competitive effects of fire-resistant saplings on their firesensitive neighbors are greater than the reverse. Ecosphere. 6: 1-14. https:// doi.org/10.1890/ES15-00116.1.

Brewer, J.S., M.J. Abbott, and S.A. Moyer. 2015. Effects of oak-hickory woodland restoration treatments on native groundcover vegetation and the invasive grass, Microstegium vimineum. Ecological Restoration 33: 256-265. https://doi. org/10.3368/er.33.3.256. 
Brose, P., T. Schuler, D. Van Lear, and J. Berst. 2001. Bringing fire back: the changing regimes of the Appalachian mixed-oak forests. Journal of Forestry 99: 30-35.

Brose, P., D. Van Lear, and R. Cooper. 1999. Using shelterwood harvests and prescribed fire to regenerate oak stands on productive upland sites. Forest Ecology and Management 113: 125-141. https://doi.org/10.1016/S03781127(98)00423-X.

Brose, P.H., D.C. Dey, R.J. Phillips, and T.A. Waldrop. 2012. A meta-analysis of the fire-oak hypothesis: does prescribed burning promote oak reproduction in eastern North America? Forest Science 59: 322-334. https://doi.org/10.5849/ forsci.12-039.

Brose, P.H., Schuler, T.M., and Ward, J.S. 2006. Responses of oak and other hardwood regeneration to prescribed fire: what we know as of 2005. In: Dickinson Matthew B., ed. 2006. Fire in eastern oak forests: delivering science to land managers, proceedings of a conference; 2005 November 15-17; Columbus, $\mathrm{OH}$. Gen. Tech. Rep. NRS-P-1. Newtown Square, PA: US Department of Agriculture, Forest Service, Northern Research Station: 123-135.

Brose, P.H., and D.H. Van Lear. 1998. Responses of hardwood advance regeneration to seasonal prescribed fires in oak-dominated shelterwood stands. Canadian Journal of Forest Research 28: 331-339. https://doi.org/10. $1139 / \times 97-218$.

Campbell, J. 2017. The bats of Tennessee, 29 pp. Nashville: Tennessee Wildlife Resources Agency.

Cannon, J.B., and J.S. Brewer. 2013. Effects of tornado damage, prescribed fire, and salvage logging on natural oak (Quercus spp.) regeneration in a xeric southern USA Coastal Plain oak and pine forest. Natural Areas Journal 33: 39-49. https://doi.org/10.3375/043.033.0105.

Conner, L.M., S.B. Castleberry, and A.M. Derrick. 2011. Effects of mesopredators and prescribed fire on hispid cotton rat survival and cause-specific mortality. The Journal of Wildlife Management 75: 938-944. https://doi.org/10.1002/ jwmg. 110

Converse, S.J., W.M. Block, and G.C. White. 2006. Small mammal population and habitat responses to forest thinning and prescribed fire. Forest Ecology and Management 228: 263-273. https://doi.org/10.1016/j.foreco.2006.03.006.

Cox, M.R., E.V. Willcox, P.D. Keyser, and A.L. Vander Yacht. 2016. Bat response to prescribed fire and overstory thinning in hardwood forest on the Cumberland Plateau, Tennessee. Forest Ecology and Management 359: 221-231. https://doi.org/10.1016/j.foreco.2015.09.048.

Dodd, L.E., M.J. Lacki, E.R. Britzke, D.A. Buehler, P.D. Keyser, J.L. Larkin, A.D. Rodewald, T.B. Wigley, P.B. Wood, and L.K. Rieske. 2012. Forest structure affects trophic linkages: how silvicultural disturbance impacts bats and their insect prey. Forest Ecology and Management 267: 262-270. https://doi.org/10. 1016/j.foreco.2011.12.016

Duffie, D.R., R.A. Gitzen, N.W. Sharp, and A.J. Turner. 2019. Effectiveness and Accuracy of Track Tubes for Detecting Small-Mammal Species Occupancy in Southeastern Herbaceous Wetlands and Meadows. Southeastern Naturalist 18 130-146. https://doi.org/10.1656/058.018.0109.

Emery, S.M., J. Uwimbabazi, and S.L. Flory. 2011. Fire intensity effects on seed germination of native and invasive Eastern deciduous forest understory plants. Forest Ecology and Management 261: 1401-1408. https://doi.org/10. 1016/j.foreco.2011.01.024.

Fisher, R.A. 1966. The Design of Experiments. 8th ed. New York: Hafner Publishing Company.

Ford, W.M., M.A. Menzel, D.W. McGill, J. Laerm, and T.S. McCay. 1999. Effects of a community restoration fire on small mammals and herpetofauna in the southern Appalachians. Forest Ecology and Management 114: 233-243. https://doi.org/10.1016/S0378-1127(98)00354-5.

Green, S.R., M.A. Arthur, and B.A. Blankenship. 2010. Oak and red maple seedling survival and growth following periodic prescribed fire on xeric ridgetops on the Cumberland Plateau. Forest Ecology and Management 259: 2256-2266. https://doi.org/10.1016/j.foreco.2010.02.026.

Greenberg, C.H., and T.A. Waldrop. 2008. Short-term response of reptiles and amphibians to prescribed fire and mechanical fuel reduction in a southern Appalachian upland hardwood forest. Forest Ecology and Management 255: 2883-2893. https://doi.org/10.1016/j.foreco.2008.01.064.

Haines, T.K., R.L. Busby, and D.A. Cleaves. 2001. Prescribed burning in the South: trends, purpose, and barriers. Southern Journal of Applied Forestry 25: 149-153. https://doi.org/10.1093/sjaf/25.4.149.

Harper, C.A., W.M. Ford, M.A. Lashley, C.E. Moorman, and M.C. Stambaugh. 2016. Fire effects on wildlife in the Central Hardwoods and Appalachian regions, USA. Fire Ecology 12: 127-159. https://doi.org/10.4996/fireecology.1202127.
Hollis, C.A., J.E. Smith, and R.F. Fisher. 1982. Allelopathic effects of common understory species on germination and growth of southern pines. Forest Science 28: 509-515.

Hutchinson, T.F., R.E.J. Boerner, S. Sutherland, E. Kennedy Sutherland, M. Ortt, and L.R. Iverson. 2005. Prescribed fire effects on the herbaceous layer of mixedoak forests. Canadian Journal of Forest Research 35: 877-890. https://doi.org/ 10.1139/x04-189.

Hutchinson, T.F., D.A. Yaussy, R.P. Long, J. Rebbeck, and E. Kennedy Sutherland. 2012. Long-term (13-year) effects of repeated prescribed fires on stand structure and tree regeneration in mixed-oak forests. Forest Ecology and Management 286: 87-100. https://doi.org/10.1016/j.foreco.2012.08.036.

Ingersoll, T.E., B.J. Sewall, and S.K. Amelon. 2016. Effects of white-nose syndrome on regional population patterns of 3 hibernating bat species. Conservation Biology 30: 1048-1059. https://doi.org/10.1111/cobi.12690.

Iverson, L.R., T.F. Hutchinson, M.P. Peters, and D.A. Yaussy. 2017. Long-term response of oak-hickory regeneration to partial harvest and repeated fires: influence of light and moisture. Ecosphere 8: e01642. https://doi.org/10.1002/ ecs2.1642.

Iverson, L.R., T.F. Hutchinson, A.M. Prasad, and M.P. Peters. 2008. Thinning, fire, and oak regeneration across a heterogeneous landscape in the eastern US: 7-year results. Forest Ecology and Management 255: 3035-3050. https://doi. org/10.1016/j.foreco.2007.09.088.

Keyser, P.D. and W.M. Ford. 2006. Influence of fire on mammals in eastern oak forests. In: Dickinson, Matthew B., ed. Fire in eastern oak forests: delivering science to land managers, proceedings of a conference; 2005 November 15-17; Columbus, OH. Gen. Tech. Rep. NRS-P-1. Newtown Square, PA: U.S. Department of Agriculture, Forest Service, Northern Research Station: 180-190

Keyser, T.L., M. Arthur, and D.L. Loftis. 2017. Repeated burning alters the structure and composition of hardwood regeneration in oak-dominated forests of eastern Kentucky, USA. Forest Ecology and Management 393: 1-11. https:// doi.org/10.1016/j.foreco.2017.03.015.

Kraig, S.E., S.M. Roels, and M.L. Thies. 2010. Effectiveness of chemical repellents in deterring Red Imported Fire Ants (Solenopsis invicta) from Sherman live traps. The Southwestern Naturalist 55: 203-206. https://doi.org/10.1894/JS-24.1.

Kreye, J.K., J.M. Varner, G.W. Hamby, and J.M. Kane. 2018. Mesophytic litter dampens flammability in fire-excluded pyrophytic oak-hickory woodlands. Ecosphere 9: e02078. https://doi.org/10.1002/ecs2.2078.

Kruger, E.L., and P.B. Reich. 1997. Responses of hardwood regeneration to fire in mesic forest openings. I. Post-fire community dynamics. Canadian Journal of Forest Research 27: 1822-1831. https://doi.org/10.1139/x97-136.

Lacki, M.J., D.R. Cox, and M.B. Dickinson. 2009. Meta-analysis of summer roosting characteristics of two species of Myotis bats. The American Midland Naturalist 162: 318-326. https://doi.org/10.1674/0003-0031-162.2.318.

Loeb, S.C., and T.A. Waldrop. 2008. Bat activity in relation to fire and fire surrogate treatments in southern pine stands. Forest Ecology and Management 255: 3185-3192. https://doi.org/10.1016/j.foreco.2007.10.060.

McGrath, D.A., J.P. Evans, C.K. Smith, D.G. Haskell, N.W. Pelkey, R.R. Gottfried, C.D. Brockett, M.D. Lane, and E.D. Williams. 2004. Mapping land-use change and monitoring the impacts of hardwood-to-pine conversion on the Southern Cumberland Plateau in Tennessee. Earth Interactions 8: 1-24. https://doi.org/10.1175/1087-3562(2004)0080001:MLCAMT2.0.CO2.

Menzel, J.M., M.A. Menzel Jr., J.C. Kilgo, W.M. Ford, J.W. Edwards, and G.F. McCracken. 2005. Effect of habitat and foraging height on bat activity in the coastal plain of South Carolina. The Journal of Wildlife Management 69: 235-245. https://doi.org/ 10.2193/0022-541X(2005)069<0235:EOHAFH>2.0.CO;2.

Menzel, M.A., T.C. Carter, W.M. Ford, B.R. Chapman, and J. Ozier. 2000. Summer roost tree selection by eastern red, Seminole, and evening bats in the Upper Coastal Plain of South Carolina. In: Proceedings of Annual Conference of Southeastern Association of Fish and Wildlife Agencies (Vol. 54). USDA Forest Service, Savannah River, New Ellenton, SC (US).

Menzel, M.A., S.F. Owen, W.M. Ford, J.W. Edwards, P.B. Wood, B.R. Chapman, and K.V. Miller. 2002. Roost tree selection by northern long-eared bat (Myotis septentrionalis) maternity colonies in an industrial forest of the central Appalachian mountains. Forest Ecology and Management 155: 107-114. https://doi.org/10.1016/S0378-1127(01)00551-5.

Nowacki, G.J., and M.D. Abrams. 2008. The demise of fire and mesophication of forests in the eastern United States. BioScience 58: 123-138. https://doi.org/ 10.1641/B580207.

Oswalt, S.N., and W.B. Smith. 2014. US forest resource facts and historical trends. Washington D.C.: United States Department of Agriculture, U.S. Forest Service. 
Owen, S.F., M.A. Menzel, J.W. Edwards, W.M. Ford, J.M. Menzel, B.R. Chapman, P.B. Wood, and K.V. Miller. 2004. Bat activity in harvested and intact forest stands in the Allegheny Mountains. Northern Journal of Applied Forestry 21: 154-159. https://doi.org/10.1093/njaf/21.3.154.

Parkins, K.L., and J.A. Clark. 2015. Green roofs provide habitat for urban bats. Global Ecology and Conservation 4: 349-357. https://doi.org/10.1016/j.gecco. 2015.07.011.

Parrott, D.L., J.M. Lhotka, J.W. Stringer, and D.N. Dillaway. 2012. Seven-year effects of midstory removal on natural and underplanted oak reproduction. Northern Journal of Applied Forestry 29: 182-190. https://doi.org/10.5849/njaf.12-001.

Poudyal, N.C., O. Joshi, D.G. Hodges, and K. Hoyt. 2014. Factors related with nonindustrial private forest landowners' forest conversion decision in Cumberland Plateau, Tennessee. Forest Science 60: 988-993. https://doi.org/ 10.5849/forsci.13-622.

Raybuck, A.L., C.E. Moorman, C.H. Greenberg, C.S. DePerno, K. Gross, D.M. Simon, and G.S. Warburton. 2012. Short-term response of small mammals following oak regeneration silviculture treatments. Forest Ecology and Management 274: 10-16. https://doi.org/10.1016/j.foreco.2012.02.012.

Reid, J.L., J.P. Evans, J.K. Hiers, and J.B.C. Harris. 2008. Ten years of forest change in two adjacent communities on the southern Cumberland Plateau, USA. The Journal of the Torrey Botanical Society 135: 224-235. https://doi.org/10.3159/ 08-RA-015.1.

SAS Institute Inc. 2002-2012. SAS/STAT Software, Version 9.4. Cary, NC http:// www.sas.com/.

Shannon, C.E., and W. Weaver. 1949. The Mathematical Theory of Communication. Urbana: University of Illinois Press.

Shapiro, S.S., and M.B. Wilk. 1965. An analysis of variance test for normality. Biometrika. 52: 591-611. https://doi.org/10.1093/biomet/52.3-4.591.

Sikes, R.S., and W.L. Gannon. 2011. Guidelines of the American Society of Mammalogists for the use of wild mammals in research. Journal of Mammalogy 92: 235-253. https://doi.org/10.1644/10-MAMM-F-355.1.

Silvis, A., S.D. Gehrt, and R.A. Williams. 2016. Effects of shelterwood harvest and prescribed fire in upland Appalachian hardwood forests on bat activity. Forest Ecology and Management 360: 205-212. https://doi.org/10.1016/j. foreco.2015.10.010

Smith, A.E. 1990. Potential allelopathic influence of certain pasture weeds. Crop Protection 9: 410-414. https://doi.org/10.1016/0261-2194(90)90129-U.

Stroup, W. 2012. Generalized linear mixed models: modern concepts, methods and applications. Boca Raton: CRC press.

Stroup, W., G. Milliken, E. Claassen, and R. Wolfinger. 2018. SAS for Mixed Models. Cary: SAS Institute.

Summerville, K.S., and M.N. Lewis. 2005. Restoring lepidopteran communities to oak savannas: contrasting influences of habitat quantity and quality. Restoration Ecology 13: 120-128. https://doi.org/10.1111/j.1526-100X.2005. 00014.x.

Tian, N., N. Poudyal, D. Hodges, T. Young, and K. Hoyt. 2015. Understanding the factors influencing nonindustrial private forest landowner interest in supplying ecosystem services in Cumberland Plateau, Tennessee. Forests 6: 3985-4000. https://doi.org/10.3390/f6113985.

Titchenell, M.A., R.A. Williams, and S.D. Gehrt. 2011. Bat response to shelterwood harvests and forest structure in oak-hickory forests. Forest Ecology and Management 262: 980-988. https://doi.org/10.1016/j.foreco.2011.05.032.

Tukey, J. 1949. Comparing individual means in the analysis of variance. Biometrics. 5: 99-114. https://doi.org/10.2307/3001913.

Waltz, A.E., and W.W. Covington. 2004. Ecological restoration treatments increase butterfly richness and abundance: mechanisms of response. Restoration Ecology 12: 85-96. https://doi.org/10.1111/j.1061-2971.2004.00262.x.

Wildlife Acoustics. 2020. https://www.wild lifeacoustics.com/.

Wolcott, D.M., M.R. Ackerman, and M.L. Kennedy. 2014. Assessing capture success of small mammals due to trap orientation in field-forest edge habitat. Canadian Field-Naturalist 128: 191-194. https://doi.org/10.22621/cfn.v128i2.1585.

Yates, M.D., and R.M. Muzika. 2006. Effect of forest structure and fragmentation on site occupancy of bat species in Missouri Ozark forests. The Journal of Wildlife Management 70: 1238-1248. https://doi.org/10.2193/0022541X(2006)70[1238:EOFSAF]2.0.CO;2.

\section{Publisher's Note}

Springer Nature remains neutral with regard to jurisdictional claims in published maps and institutional affiliations.

\section{Submit your manuscript to a SpringerOpen ${ }^{\circ}$ journal and benefit from:}

- Convenient online submission

Rigorous peer review

- Open access: articles freely available online

- High visibility within the field

- Retaining the copyright to your article

Submit your next manuscript at $\boldsymbol{\nabla}$ springeropen.com 